\title{
Short Communication: Effect of Increasing Levels of Corn Bran on Milk Yield and Composition ${ }^{1}$
}

\author{
B. N. Janicek, ${ }^{\star}$ P. J. Kononoff, ${ }^{\star 2}$ A. M. Gehman, ${ }^{*}$ K. Karges, $†$ and M. L. Gibson $†$ \\ *Department of Animal Science, University of Nebraska, Lincoln 68583-0908 \\ †Dakota Gold Research Association, Sioux Falls, SD 57104
}

\begin{abstract}
Thirty-nine lactating Holstein cows (23 multiparous and 16 primiparous) were randomly assigned to 1 of 3 dietary treatments in a crossover design. Dietary treatments differed by the proportion of corn bran $[10,17.5$, and $25 \%$ dry matter (DM); designated as low, medium, and high] replacing corn silage and alfalfa. The corn bran coproduct contained $8.2 \%$ moisture and $12.9 \%$ crude protein, $30.4 \%$ neutral detergent fiber (NDF), and $45.0 \%$ nonfiber carbohydrate, $9.9 \%$ ether extract, and $0.70 \% \mathrm{P}$ (DM basis). The low treatment consisted of $15.8 \%$ NDF from forage (fNDF) and $33.1 \%$ total NDF; the medium treatment consisted of $12.9 \% \mathrm{fNDF}$ and $32.5 \%$ total NDF; and the high diet contained 9.9\% fNDF and $31.8 \%$ total NDF. Dry matter intake was not affected by treatment. The percent milk fat decreased by $0.26 \%$ with the inclusion of corn bran from 10 to $25 \%$ of the diet DM, but total milk fat yield was not affected. In comparison, corn bran increased yield of milk protein $0.12 \mathrm{~kg} / \mathrm{d}$ when bran increased from 10 to $25 \%$ of the diet DM. Total milk yield tended to increase when bran increased from 10 to $25 \%$ of the diet DM, but no differences were observed on $3.5 \%$ fat-corrected milk. Lastly, feed conversion significantly improved with increasing inclusion: $1.39,1.39$, and $1.55 \pm 0.05$ $\mathrm{kg}$ of milk/kg of DMI for low, medium, and high, respectively. Observed effects were likely due to the increase in energy intake associated with increasing levels of corn bran.
\end{abstract}

Key words: corn bran, ethanol coproduct, milk, lactation

The recently passed Energy Policy Act (EPACT, 2005) mandates up to 7.5 billion gallons of renewable fuel to

Received April 11, 2007.

Accepted May 4, 2007.

${ }^{1} \mathrm{~A}$ contribution of the University of Nebraska Agricultural Research Division, supported in part by funds provided through Hatch Act. Additional support was provided by Dakota Gold Research Association, Sioux Falls, SD.

${ }^{2}$ Corresponding author: pkononoff2@unl.edu be used by 2012 and will result in a dramatic increase in the availability of corn milling coproducts. The inclusion of coproducts such as corn distillers grains with solubles (DDGS) into dairy diets has been demonstrated to maintain milk production (Schingoethe et al., 1999) but are usually fed in limited amounts because of the potential to negatively affect milk fat percentage (Leonardi et al., 2005). Traditional corn-ethanol production employs a system in which the whole corn kernel is ground, cooked, and then fermented to produce ethanol. An alternative to this method is separating the kernel into its 3 major components, namely bran, germ, and endosperm, prior to fermentation. These components are then spared the fermentation processes and may be used for animal feed. Compared with traditional DDGS, corn bran is similar in NDF but lower in CP. Because corn bran is not exposed to the fermentation process, it is generally a better quality nutrient source. The objective of this research was to evaluate the effects of increasing levels of a corn bran coproduct on milk production and composition.

Thirty-nine lactating Holstein cows (23 multiparous and 16 primiparous) were randomly assigned to 1 of 3 dietary treatments in a 3-period crossover design. The experiment was conducted in 2 phases, with 20 animals in phase 1 and 19 animals in phase 2 . Cows were housed in individual stalls and milked at 0730 and $1930 \mathrm{~h}$. Cows were fed at $0800 \mathrm{~h}$ for ad libitum consumption to allow for approximately $5 \%$ refusal. During each of the 21-d periods, cows were offered 1 of 3 rations (Table 1) that differed by the concentration of corn bran that replaced alfalfa hay, alfalfa haylage, and corn silage. Dietary treatments were 1) low, $10 \% \mathrm{DM}$ bran, 2) medium, 17.5\% DM bran, and 3) high, 25\% DM bran. The experimental cows were cared for according to the guidelines stipulated by the University of NebraskaLincoln Animal Care and Use Committee.

Samples of feed were collected weekly and composited by experimental period. Collected samples were immediately frozen $\left(-20^{\circ} \mathrm{C}\right)$ and stored for further analysis. Before analysis samples were dried at $60^{\circ} \mathrm{C}$ in a forcedair oven and ground (1-mm screen; Wiley mill, Arthur H. Thomas Co., Philadelphia, PA) and analyzed as de- 
Table 1. Chemical analysis and diet ingredients

\begin{tabular}{|c|c|c|c|}
\hline \multirow[b]{2}{*}{ Ingredient (\% of DM) } & \multicolumn{3}{|c|}{ Treatment $^{1}$} \\
\hline & Low & Medium & High \\
\hline Corn silage & 23.0 & 18.8 & 14.5 \\
\hline Alfalfa hay & 8.7 & 7.1 & 5.47 \\
\hline Alfalfa haylage & 8.7 & 7.1 & 5.47 \\
\hline Corn grain & 14.7 & 14.7 & 14.7 \\
\hline $\mathrm{Bran}^{2}$ & 10.2 & 17.5 & 25.0 \\
\hline Soybean hulls & 12.6 & 12.6 & 12.6 \\
\hline Soybean meal & 6.9 & 6.9 & 6.9 \\
\hline Soypass $^{3}$ & 5.7 & 5.7 & 5.7 \\
\hline Limestone & 1.7 & 1.7 & 1.7 \\
\hline Cottonseed & 6.5 & 6.5 & 6.5 \\
\hline Sodium bicarbonate & 0.70 & 0.70 & 0.70 \\
\hline Magnesium oxide & 0.17 & 0.17 & 0.17 \\
\hline Salt & 0.11 & 0.11 & 0.11 \\
\hline Vitamin E & 0.02 & 0.02 & 0.02 \\
\hline Selplex ${ }^{4}$ & 0.01 & 0.01 & 0.01 \\
\hline Vitamin A, D, $\mathrm{E}^{5}$ & 0.13 & 0.13 & 0.13 \\
\hline Trace mineral ${ }^{6}$ & 0.04 & 0.04 & 0.04 \\
\hline \multicolumn{4}{|l|}{ Chemical composition } \\
\hline $\mathrm{CP}, \%$ of $\mathrm{DM}$ & 18.4 & 18.2 & 18.1 \\
\hline RUP, $\%$ of DM & 6.6 & 6.5 & 6.4 \\
\hline $\mathrm{NDF}, \%$ of DM & 33.1 & 32.5 & 31.8 \\
\hline $\mathrm{NFC}, 7 \%$ of DM & 38.3 & 39.0 & 39.7 \\
\hline Ether extract, \% of DM & 4.9 & 5.3 & 5.7 \\
\hline Phosphorus & 0.34 & 0.38 & 0.42 \\
\hline \multicolumn{4}{|l|}{ Particle size } \\
\hline$>19.0 \mathrm{~mm}$ & 5.7 & 4.8 & 4.5 \\
\hline 19.0 to $8.0 \mathrm{~mm}$ & 26.3 & 23.7 & 21.4 \\
\hline 8.0 to $1.18 \mathrm{~mm}$ & 42.9 & 44.4 & 43.5 \\
\hline$<1.18 \mathrm{~mm}$ & 25.2 & 27.1 & 30.7 \\
\hline
\end{tabular}

${ }^{1}$ Rations containing increasing levels of corn bran; low (10\% DM), medium (17.5\% DM), and high (25\% DM).

${ }^{2}$ Dakota Gold Marketing Inc., Sioux Falls, SD.

${ }^{3}$ LignoTech, Overland Park, KS.

${ }^{4}$ Alltech Inc., Nicholasville, KY.

${ }^{5}$ Formulated to supply approximately $120,000 \mathrm{IU} / \mathrm{d}$ of vitamin A, $24,000 \mathrm{IU} / \mathrm{d}$ of vitamin $\mathrm{D}$, and $800 \mathrm{IU} / \mathrm{d}$ of vitamin $\mathrm{E}$.

${ }^{6}$ Formulated to contained $1.0 \% \mathrm{Ca}, 0.50 \% \mathrm{P}, 0.36 \% \mathrm{Mg}, 1.3 \% \mathrm{~K}$.

${ }^{7} \mathrm{NFC}$ calculated by difference: $100-(\% \mathrm{NDF}+\% \mathrm{CP}+\%$ ether extract $+\%$ ash).

scribed by Kononoff et al. (2006). For determination of NDF, $\alpha$-amylase and sodium sulphite were used (Mertens, 2002). The Penn State Particle Separator was used to measure particle size for all rations (Kononoff et al., 2003). Body weight was measured on the last 2 $\mathrm{d}$ of each period, but BCS ( $1-5$ scale) was measured on the last day of each period. Body condition score was measured by a single trained individual and differed from that described by Wildman et al. (1982) because it was reported to the quarter point. Milk production was measured daily, and milk samples were collected on d 20 and 21 of each period during the AM and PM milking and preserved using 2-bromo-2-nitropropane1,3 diol. Milk samples were analyzed for fat and true protein (AOAC, 1990) using a B2000 Infrared Analyzer (Bentley Instruments, Chaska, MN) by Heart of America DHIA (Manhattan, KS). Daily DMI and milk yield were averaged weekly.
Milk production, milk composition, intake, and BCS data were analyzed using the MIXED procedure of SAS (Version 9.1, SAS Institute Inc., Cary, NC) according to the following model: $\mathrm{y}_{\mathrm{ijklm}}=\mu+b_{\mathrm{ij}}+\rho_{\mathrm{k}}+\gamma_{\mathrm{l}}+\lambda_{\mathrm{m}}+$ $\pi_{\mathrm{n}}+e_{\mathrm{ijk} l m}$, where $\mu$ is the general mean, $b_{\mathrm{ij}}$ is the random effect of the jth cow within the ith sequence, $\rho_{\mathrm{k}}$ is the effect of the kth period, $\gamma_{1}$ is the fixed effect of the effect of the lth diet, $\lambda_{\mathrm{m}}$ is the fixed effect of the mth parity, $\pi_{\mathrm{n}}$ is the fixed effect of the nth experimental phase, and $e_{\mathrm{ijk}}$ reflects the random error in the measurement of the response. Linear, quadratic, and cubic orthogonal contrasts were tested using the CONTRAST statement of SAS.

The corn bran coproduct (Dakota Gold Marketing, Sioux Falls, SD) contained $8.2 \%$ moisture and $12.9 \%$ $\mathrm{CP}, 30.4 \% \mathrm{NDF}$, and $45.0 \% \mathrm{NFC}, 9.9 \%$ ether extract, and $0.70 \% \mathrm{P}$ when expressed on a DM basis. This chemical analysis outlines the major differences in chemical composition that may exist amount corn milling coproducts. Specifically, compared with the corn bran coproduct, DDGS typically contain similar levels of NDF (38.8\%) and fat (10.0\%) but higher levels of CP (29.7\%; NRC, 2001).

Diets were formulated to contain 3 levels of the bran, which replaced a portion of the forages. The chemical composition of the diets fed were similar (Table 1), containing approximately $18 \% \mathrm{CP}$, but increasing the levels of bran resulted in a modest decrease in total diet NDF: $33.1,32.5$, and 31.8\% DM for low, medium, and high treatments, respectively. The concentrations of ether extract and NFC were also different (ether extract $=4.9,5.3,5.7 \% \mathrm{DM}$ and $\mathrm{NFC}=38.3,39.0$, and $39.7 \% \mathrm{DM}$ for low, medium, and high, respectively). The diet $\mathrm{P}$ content increased from $0.34,0.38$, and $0.42 \%$ as corn bran was included in the diet from 10, 17.5, and $25 \%$ of the diet DM. The TMR particle size analysis is also presented in Table 1. Ration particle size reflected the amount of bran included in the treatments. Increasing inclusion of bran reduced the proportion of material on the $19.0-\mathrm{mm}$ screen $(5.7,4.8,4.5 \%)$, but increased the proportion retained on the pan $(<1.18$ $\mathrm{mm} ; 25.2,27.1,30.7 \%$ ).

Increasing the level of bran did not affect DMI, which averaged $23.8 \pm 0.73 \mathrm{~kg} / \mathrm{d}$ across treatments (Table 2). Milk yield tended $(P=0.07)$ to increase linearly with increasing concentrations of bran: $32.7,33.4,35.8 \pm$ $1.30 \mathrm{~kg} / \mathrm{d}$ for low, medium, and high, respectively (Table 2). As a consequence of lack of effect on DMI and effect on milk yield, feed conversion significantly improved with increasing inclusion: $1.39,1.39$, and $1.55 \pm 0.05$ $\mathrm{kg}$ of milk/kg of DMI for low, medium, and high, respectively. The observation that the feeding of corn milling coproducts may result in increased milk yield but not intake is in contrast to that of Owen and Larson (1991). 
Table 2. The effect of feeding corn bran on milk production and composition of Holstein dairy cows

\begin{tabular}{|c|c|c|c|c|c|c|}
\hline \multirow[b]{2}{*}{ Item } & \multicolumn{3}{|c|}{ Treatment $^{1}$} & \multirow[b]{2}{*}{$\mathrm{SEM}^{2}$} & \multicolumn{2}{|c|}{$P$-value } \\
\hline & Low & Medium & High & & Linear & Quadratic \\
\hline DMI, kg/d & 23.6 & 24.2 & 23.6 & 0.73 & 0.91 & 0.54 \\
\hline Energy intake,$^{3} \mathrm{Mcal} / \mathrm{d}$ & 38.4 & 40.2 & 41.1 & 1.30 & 0.15 & 0.76 \\
\hline Milk yield, $\mathrm{kg} / \mathrm{d}$ & 32.7 & 33.4 & 35.8 & 1.30 & 0.07 & 0.59 \\
\hline Fat, $\%$ & 3.58 & 3.50 & 3.32 & 0.10 & 0.06 & 0.70 \\
\hline Protein, \% & 2.99 & 2.97 & 3.06 & 0.04 & 0.17 & 0.23 \\
\hline $\mathrm{MUN}, \mathrm{mg} / \mathrm{dL}$ & 14.8 & 14.9 & 13.9 & 0.34 & 0.05 & 0.14 \\
\hline $3.5 \% \mathrm{FCM}$ & 32.9 & 33.57 & 34.30 & 1.29 & 0.40 & 0.97 \\
\hline Lactose, \% & 4.78 & 4.75 & 4.82 & 0.05 & 0.49 & 0.39 \\
\hline Fat yield, $\mathrm{kg} / \mathrm{d}$ & 1.16 & 1.18 & 1.16 & 0.05 & 0.94 & 0.75 \\
\hline Protein yield, kg/d & 0.97 & 1.00 & 1.09 & 0.04 & 0.02 & 0.44 \\
\hline Feed conversion, $\mathrm{kg}$ of milk/kg of DMI & 1.39 & 1.39 & 1.55 & 0.05 & 0.03 & 0.19 \\
\hline BCS & 3.29 & 3.27 & 3.27 & 0.05 & 0.76 & 0.80 \\
\hline
\end{tabular}

In that study, DDGS replaced primarily soybean meal and diets were of low protein content. These authors suggested that intakes were increased by feeding DDGS because a greater amount of amino acids were required to maintain maximal milk production. Thus it is possible that in the current experiment intakes were similar across treatments because the coproduct replaced forage, and based on the NRC (2001) model, experimental diets were formulated to be higher in $\mathrm{CP}$ and adequate in MP. This suggestion is further supported because a lack of effect of DMI has also been observed when DDGS replace forage in the form of alfalfa haylage (Clark and Armentano, 1993).

A common field concern related to feeding many corn milling coproducts is the high fat content. It is now generally understood that a buildup of the unsaturated fatty acid, linoleic acid, in the rumen may lead to events that can cause milk fat depression (Baumgard et al., 2000). Generally speaking, coproducts are high in fat and are a rich source of linoleic acid. Although bran resulted in a tendency $(P=0.06)$ for a reduction of the concentration of milk fat, total milk yield was increased, so there were no differences in total milk fat yield. This response is similar to Leonardi et al. (2005), who increased the proportion of DDGS in a ration from 0 to $15 \%$ DM. Practically, these data also outline the importance of understanding effects on milk composition and total milk yield before implicating corn milling coproducts as a cause for low milk fat tests. In comparison to percent fat, differences in the concentration of milk protein were not observed (mean $=3.00 \pm 0.04 \%$ ). However, total protein yield was significantly increased for cows consuming more bran $(0.97,1.00$, and $1.09 \mathrm{~kg} /$ $\mathrm{d}$ for low, medium, and high, respectively) due to greater milk yield. This response is possibly due to improved energy status of cows consuming bran, as energy intake is positively correlated with milk protein synthesis (Grieve et al., 1986). The diets containing bran may have provided more ruminally fermentable OM resulting in higher amounts of propionate for use in gluconeogenesis and amino acids being spared for protein synthesis (Harvatine et al., 2002). No statistical differences were observed on $3.5 \% \mathrm{FCM}$ with increasing levels of bran.

Compared with other studies evaluating health and reproduction (Windig et al., 2005), the current study contained a small number of animals and should be interpreted with caution. During the second phase of the experiment, 3 animals were diagnosed with displaced abomasums, and data from these animals were removed from the data set. Two animals were diagnosed while consuming the high treatments, and one was diagnosed while consuming the medium treatment. The reason for these observations is unclear but may have been a result of a reduction in effective fiber when the bran replaced forage. The NRC (2001) recommends dairy diets contain at least $25 \% \mathrm{NDF}$ with at least 19\% from forage (fNDF) and an upward adjustment in ration NDF content if fNDF content is reduced. In the current experiment, the low treatment consisted of $15.8 \% \mathrm{fNDF}$ and $33.1 \% \mathrm{NDF}$, which is in the recommended range of minimum total and forage NDF. In comparison, the high diet contained 9.9\% fNDF and $31.8 \% \mathrm{NDF}$, which is below recommended levels. Practically, health results of the current experiment suggest that the bran coproduct is a feedstuff with high nutrient quality but should be included into dairy diets balanced to contain adequate levels of effective fiber. 


\section{REFERENCES}

Association of Official Analytical Chemists. 1990. Official Methods of Analysis. 15th ed. AOAC, Arlington, VA.

Baumgard, L. H., B. A. Corl, D. A. Dwyer, A. Saebo, and D. E. Bauman. 2000. Identification of the conjugated linoleic acid isomer that inhibits milk fat synthesis. Am. J. Physiol. 278:R179-R184.

Clark, P. W., and L. E. Armentano. 1993. Effectiveness of neutral detergent fiber in whole cottonseed and dried distillers grains compared with alfalfa haylage. J. Dairy Sci. 76:2644-2650.

Energy Policy Act (EPACT). 2005. Public Law 109-58. http://www. frwebgate.access.gpo.gov/cgi-bin/getdoc.cgi?dbname=109_cong public_laws\&docid=f:publ058.109 Accessed Apr. 2, 2006.

Grieve, D. G., S. Korver, Y. S. Rijpkema, and G. Hof. 1986. Relationship between milk composition and some nutritional parameters in early lactation. Livest. Prod. Sci. 14:239-254.

Harvatine, D. I., J. L. Firkins, and M. L. Eastridge. 2002. Whole linted cottonseed as a forage substitute fed with ground or steamflaked corn: Digestibility and performance. J. Dairy Sci. 85:1976-1987.

Kononoff, P. J., A. J. Heinrichs, and D. A. Buckmaster. 2003. Modification of the Penn State forage and TMR separator and the effects of moisture content on its measurements. J. Dairy Sci. 86:1858-1863.
Kononoff, P. J., S. Ivan, W. Matzke, R. J. Grant, R. Stock, and T. J. Klopfenstein. 2006. Milk production of dairy cows fed a wet corn gluten feed during the dry period and lactation. J. Dairy Sci. 89:2608-2617.

Leonardi, C., S. Bertics, and L. E. Armentano. 2005. Effect of increasing oil from distillers grains or corn oil on lactation performance. J. Dairy Sci. 88:2820-2827.

Mertens, D. R. 2002. Gravimetric determination of amylase-treated neutral detergent fiber in feeds using refluxing in beakers or crucibles: Collaborative study. J. AOAC 85:1217-1240.

NRC. 2001. Nutrient Requirements of Dairy Cattle. 7th rev. ed. Natl. Acad. Sci., Washington, DC.

Owen, F. G., and L. L. Larson. 1991. Corn distillers dried grains versus soybean meal in lactation diets. J. Dairy Sci. 74:972-979.

Schingoethe, D. J., M. J. Brouk, and C. P. Birkelo. 1999. Milk production and composition from cows fed wet corn distillers grains. J. Dairy Sci. 82:574-580.

Wildman, E. E., G. M. Jones, P. E. Wagner, H. F. Troutt, and T. N Lesch. 1982. A dairy cow body condition scoring system and its relationship to selected production characteristics. J. Dairy Sci. 65:495-501.

Windig, J. J., M. P. L. Calus, and R. F. Veerkamp. 2005. Influence of herd environment on health and fertility and their relationship with milk production. J. Dairy Sci. 88:335-347. 